\title{
International Student Agency in the Face of a Global Health Crisis
}

\author{
Megan Siczek \\ The George Washington University, USA
}

Much of the literature on international students in U.S. higher education - as well as the perception of many within our institutional communities-focuses on the challenges these globally mobile students may experience. Challenges related to acculturation, English language proficiency, academic adjustment, and cross-cultural interactions are prevalent in research (Smith \& Khawaja, 2011). However, research has also demonstrated international students' ability to succeed academically in spite of some of these challenges as a result of their motivation, effort, and persistence (Andrade, 2006). This maps with my own research finding that international students negotiate their sociaocademic experiences in the mainstream U.S. college curriculum with self-awareness and a sense of agency that allows them to shape their own learning experiences (Siczek, 2018).

This is the story of how a group of English for Academic Purposes (EAP) students at a private university in Washington, DC, demonstrated resilience and agency in the face of a global health pandemic.

In spring 2020, when the COVID-19 pandemic began to affect the United States, these students were enrolled in my on-campus undergraduate course called "Oral Academic Communication for International Students." The main content of the course draws on students' global experiences and linguistic assets while preparing them to meet the communicative expectations of the U.S. undergraduate curriculum. It is usually a highly interactive and productive class that covers a variety of oral academic genres, with students gaining authority and voice as the semester progresses.

We were halfway through the semester when students at our university were told that they were expected to go home for spring break and await an announcement about whether they should return to campus. Of course, going home was not an easy option for a group of students from Austria, China, Germany, Pakistan, South Korea, and Taiwan. As the end of spring break neared, students were told that the rest of the 
semester would be taught online. International students could head home or petition the university for continued accommodation on campus. Students and their families were forced to make quick decisions, balancing the competing priorities of health and academics. By the final weeks of the semester, only three students in my class remained in the United States: One was in her third campus housing location in less than a month; one had moved to a local hotel, where she would stay to finish the semester; and one moved into a rented room in an AirBnB house in the suburbs of Washington, DC. The rest of my students endured long journeys to their home countries, often spending weeks in hotel- or facility-based quarantine before being allowed to return to their family homes. Throughout this disruption, online learning continued.

How did students manage the course despite this disruption and dislocation? They showed up; they engaged; they connected with and cared for one another; they learned. I was amazed and inspired by their response. The students who could joined synchronous sessions online during our usual class time, entering the "room" fully prepared and contributing actively to class activities and discussions. Those who could not join watched recorded versions of each class session and posted multimodal alternate assignments in which they engaged with the learning material as well as the ideas their classmates had discussed during the synchronous class.

While we were online during the second half of the semester, students virtually facilitated discussions on self-selected TED Talks covering global and cross-cultural themes, designed and shared internationally oriented infographics that applied best practices for visual communication, practiced vocal techniques for oral presentations, and designed and delivered individual presentations proposing an initiative to advance internationalization on campus. These persuasive presentations were grounded in scholarly literature on the internationalization of higher education and situated in the local context of the university and its needs. Students proposed initiatives such as an international research hub on campus, the enhancement of the university's foreign language requirement to promote global competence, a new curricular requirement focusing on global diversity and inclusion, a peer-pairing program for domestic and international students, and even a global health crisis headquarters so that the university could address pandemics like COVID-19 with a higher level of preparedness and coordination. Their presentations were uniquely informed by the global perspectives they had developed based on their own transnational migration experiences and were delivered with remarkable professionalism despite conditions being far different from the intended classroombased presentation.

During our 6 weeks of online learning, my contact with students was high, and I had a new window into their lives outside of the classroom and the extent to which they invested in their educations. I was witness to the resilience these students displayed as they negotiated this unsettling global crisis. I posit that these international students were primed to adapt - and even thrive - during this global crisis because they themselves had crossed cultural, linguistic, geographical, and even epistemological boundaries to pursue higher education in the United States. Thus, my call to action as I wrap up this $10^{\text {th }}$ anniversary essay for the Journal of International Students is that we continue to engage in qualitative inquiry into the lived experience 
of globally mobile students in our institutional settings, targeting research that illuminates their global interconnectedness and the agency they display as they navigate new and uncertain socioacademic terrain.

\section{REFERENCES}

Andrade, M. S. (2006). International students in English-speaking universities: Adjustment factors. Journal of Research in International Education, 5(2), 131154.

Siczek, M. (2018). International students in first-year writing classes: A journey through socioacademic space. University of Michigan Press.

Smith, R. A., \& Khawaja, N. G. (2011). A review of the acculturation experiences of international students. International Journal of Intercultural Relations, 35(6), 699-713.

MEGAN SICZEK, $\mathrm{PhD}$, is an Associate Professor of English for Academic Purposes (EAP) at the George Washington University in Washington, DC. Her research interests include second language writing, English as a global language, and the internationalization of higher education. She is the author of a number of articles and book chapters about global education initiatives and second language writing, as well as the book International Students in First-Year Writing: A Journey through Socio-Academic Space. Email: msiczek@gwu.edu 